\title{
Spatio-temporal analysis of Typhoid Fever in Meknes City (Morocco)
}

\section{Omar Mouhaddach}

\section{Q OpenEdition}

\section{Journals}

Electronic version

URL: http://journals.openedition.org/rfst/787

DOI: $10.4000 /$ rfst.787

ISSN: 2492-3672

\section{Publisher}

Espaces et SOciétés (UMR 6590)

Electronic reference

Omar Mouhaddach, "Spatio-temporal analysis of Typhoid Fever in Meknes City (Morocco)", Revue francophone sur la santé et les territoires [Online], Varia, Online since 13 May 2015, connection on 06 April 2021. URL: http://journals.openedition.org/rfst/787 ; DOI: https://doi.org/10.4000/rfst.787

This text was automatically generated on 6 April 2021.

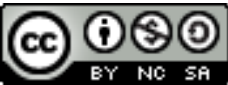

La Revue francophone sur la santé et les territoires est mise à disposition selon les termes de la Licence Creative Commons Attribution - Pas d'Utilisation Commerciale - Partage dans les Mêmes Conditions 4.0 International. 


\title{
Spatio-temporal analysis of Typhoid Fever in Meknes City (Morocco)
}

\author{
Omar Mouhaddach
}

\section{EDITOR'S NOTE}

With collaboration of: Mohamed Ben-Daoud [contributeur], Université Moulay Ismail Faculté des Sciences de Meknès (Maroc)Sophie Vanwambeke [contributeur], Université Catholique de Louvain - Louvain-la-Neuve (Belgique)Marie-Paule Kestemont [contributeur], Université Catholique de Louvain - Louvain-la-Neuve (Belgique) Samir El Jaafari [contributeur], Université Moulay Ismail - Faculté des Sciences de Meknès (Maroc).

\section{Background}

1 With an annual incidence above the national average, typhoid fever is a major public health problem in Meknes city (Morocco). The factors influencing the spatial and temporal distribution of this disease across the city are poorly understood.

2 Health officers suspect that wastewater is reused to a high extent to irrigate agricultural land in urban and suburban areas. However, illiteracy rates, availability of basic amenities and socio-economic disparities may also influence the spatial distribution of the disease.

3 Analysis of the geographical distribution of typhoid in Meknes city, as well as the study of its relation to potential risk factors, is important in developing an efficient system for the monitoring and prevention of this food and waterborne disease. 


\section{Methods}

4 This study aims to analyse the spatio-temporal pattern of typhoid fever in Meknes city over the period 2008-2010, considering the following hypotheses: (i) the typhoid incidence has a tendency to aggregate in our study area; (ii) the typhoid incidence is higher among the people living close to fields irrigated by wastewater; and (iii) the illiteracy rate and the availability of basic amenities (kitchen, toilet and bath) can influence the disease distribution at local level.

5 The data concerning the patients with typhoid fever were obtained from the Provincial Delegation of Public Health in Meknes, geocoded to sub-communal tract level and used in space-time analysis together with demographic, educational, environmental and basic amenities variables.

6 In addition to addressing the spatio-temporal pattern of typhoid fever, we attempt to provide an overview of the environmental factors: the reuse of wastewater in urban and suburban areas.

\section{Results}

7 Wastewater reuse for agriculture is common in Morocco, but particularly in Meknes city, where it occurs over approximately 2245 ha. The areas where wastewater is reused are distributed over the valleys of three rivers: Bouisshak, Boufekrane and Ouislane.

The Bouisshak area is the most affected by this practice (93\% of the area is irrigated by raw wastewater), followed by Ouislane (71\%), and finally Boufekrane (69\%). Vegetables from these areas supply a large quantity of the produce sold at the informal markets of Meknes city; this creates a health risk to consumers. Thus, we investigate the distribution of the health risk associated with typhoid fever in Meknes city. The general spatial autocorrelation analyses have rejected the null hypothesis corresponding to a random distribution during the years $2008(\mathrm{p}<0.05)$ and $2010(\mathrm{p}<0.01)$. These results show that the typhoid fever incidence tends to aggregate in Meknes city.

9 To confirm this finding and to understand this trend, we proceeded with the mapping of the high and low risk clusters, using local spatial autocorrelation analyses. The spatial scan of Kulldorff has elucidated the existence of a spatial gradient. Specifically, the high risk clusters were mainly aggregated in the Northwest of the city, close to the areas of wastewater reuse, whereas the low risk clusters in the Southeast.

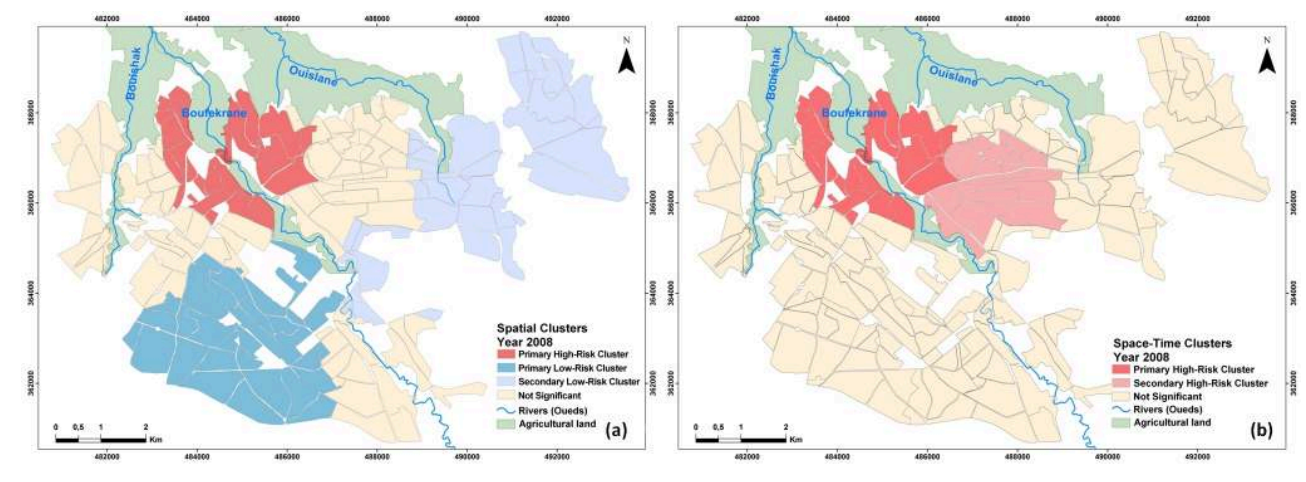


10 According to the spatio-temporal approach, this gradient occurs during the summer season (May-October) due to the intensive use of wastewater in agriculture and scarcity of water resources during this period.

11 Nonparametric correlation has revealed a statistically significant association between the incidence of typhoid fever and the proximity to areas of wastewater reuse in agriculture. No statistical association was found with the illiteracy rate and basic amenities variables.

\section{Conclusion}

12 A better understanding of the spatial distribution patterns of typhoid fever will help to identify areas and populations at high risk and assist public health officers of Meknes city to plan actions to reduce the risk of food and waterborne disease.

INDEX

Geographical index: Meknes, Morocco

Keywords: typhoide fever, spatio-temporal distribution, statistical analysis

\section{AUTHOR}

OMAR MOUHADDACH

Université Moulay Ismail - Faculté des Sciences de Meknès (Maroc) 